Article

\title{
Exploring Tourism Recovery in the Post-COVID-19 Period: An Evolutionary Game Theory Approach
}

\author{
Hui Yan, Haixiang Wei * (D) and Min Wei \\ School of Management, Xiamen University, Xiamen 361005, China; yanhui@xmu.edu.cn (H.Y.); \\ xiada2000@126.com (M.W.) \\ * Correspondence: weihaixiang93@126.com
}

check for updates

Citation: Yan, H.; Wei, H.; Wei, M Exploring Tourism Recovery in the Post-COVID-19 Period: An Evolutionary Game Theory Approach. Sustainability 2021, 13, 9162. https://doi.org/10.3390/ su13169162

Academic Editor: Alan Fyall

Received: 21 June 2021

Accepted: 9 August 2021

Published: 16 August 2021

Publisher's Note: MDPI stays neutral with regard to jurisdictional claims in published maps and institutional affiliations.

Copyright: (c) 2021 by the authors. Licensee MDPI, Basel, Switzerland. This article is an open access article distributed under the terms and conditions of the Creative Commons Attribution (CC BY) license (https:// creativecommons.org/licenses/by/ $4.0 /)$.

\begin{abstract}
This study aims to explore the process of tourism recovery in the post-COVID-19 period and the role of stakeholders in promoting such a process. Using evolutionary game theory, this study analyzes the behavior interactions and game equilibrium of stakeholders in the development of tourism by constructing an evolutionary game model amongst governments, tourists and tourism enterprises. Then, the influences of different evolution paths and major parameters affecting stakeholders' strategy selection are discussed. With the aim of illustrating the role of the stakeholders in the tourism sector's economic recovery under the impact of the coronavirus pandemic, the numerical experiment was conducted using the MATLAB 2016 software. The results show that the development and change of the emergent public health events affect tourism stakeholders' behavior strategy. Moreover, the strategic choices of each player, including governments, tourism enterprises and tourists, are also constantly evolving at different stages of the pandemic.
\end{abstract}

Keywords: post-COVID-19 period; tourism recovery; evolutionary game theory; stakeholders

\section{Introduction}

Public health emergencies are related to major infectious disease outbreaks that occur suddenly, mass diseases of unknown causes, major food and occupational poisoning and other events that seriously affect public health [1], such as SARS, the avian flu, H1N1, etc. The COVID-19 outbreak that occurred in the early months of 2020 was listed as a public health emergency of international concern (PHEIC) by the World Health Organization (WHO, Figure 1). There is no doubt that COVID-19 is one of the most influential events of the 21st century [2]. Moreover, the ensuing pandemic caused a significant decrease in the number of international tourists in the first quarter of $2020(-22 \%)$ [3] and over 150 million travel and tourism jobs have been lost since the outbreak began [4]. Specifically, the limited population movement under the influence of the pandemic caused great shock to those areas related to holiday consumption [5], such as the transportation sector (e.g., civil aviation, railway and automobile passenger transportation) and the industries directly related to people's terminal consumption, including cinema and catering. Since mid-May, after implementing stringent safety protocols, more and more countries have announced measures to restart their respective tourism industries to actively promote the development of domestic tourism [3].

Scott and Laws [6] mentioned that the impact of the crisis can be seen in the system of interconnections between enterprises and other stakeholders that constitute the tourism destinations. In the post-pandemic period, the response to crises and tourism recovery cannot be separated from stakeholders. Previous studies have explored the impacts of the pandemic on stakeholder' behaviors, such as resident behaviors [7], tourist behaviors [8] and tourism enterprise behaviors [9]. However, it should be noted that tourism recovery is a holistic system that cannot separate the links amongst stakeholders. Therefore, it is more appropriate to consider how to promote post-pandemic tourism recovery based on the pandemic-related changes in tourism stakeholders and their interaction behaviors. 


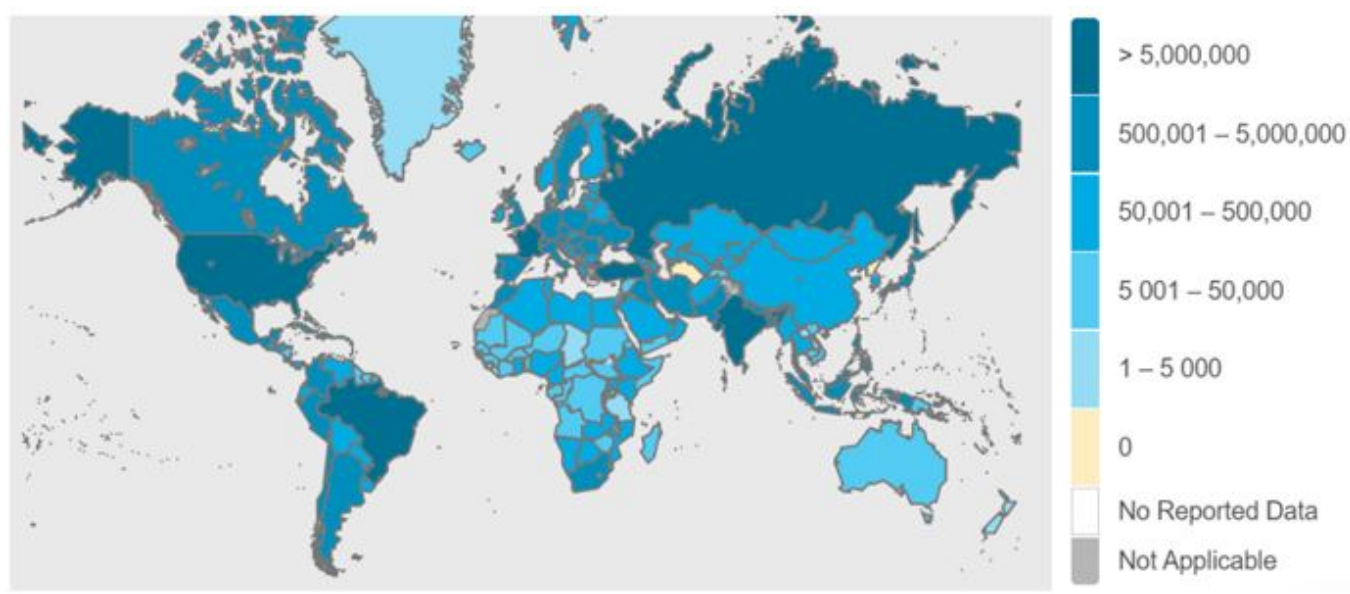

Figure 1. WHO coronavirus disease (COVID-19) dashboard. Note: Globally, as of 5:31pm CEST, 18 June 2021, there have been 177,108,695 confirmed cases of COVID-19, including 3,840,223 deaths, reported to the WHO. Source: World Health Organization. https: / / covid19.who.int/ (accessed on 18 June 2021).

This study applies an evolutionary game approach to the analysis of the possible behaviors and strategic choices of key stakeholders in the post-pandemic period, including tourism enterprises, governments and tourists. Evolutionary game models amongst stakeholders are constructed after the formation of assumed parameters. Finally, the interaction behaviors of stakeholders are simulated to address the post-pandemic tourism recovery process.

In order to achieve the above research objectives, this study constructs an evolutionary game model to discuss the possible behavioral interactions amongst governments, tourism enterprises and tourists. Using game equilibrium, we then explain the specific mechanism employed by interested subjects in order to achieve tourism recovery after the pandemic. Towards this end, the research questions to be addressed in this study include the following:

1. What changes have taken place in tourism enterprises, governments and tourists under the impact of the pandemic?

2. Under the influence of different parameters, what is the possible behavioral evolution of these stakeholders?

3. What should stakeholders do under the optimal evolutionary path (tourism recovery)?

Based on the further analysis of the evolution paths and the variation of the main parameters, the evolutionary stable strategy (ESS) under different conditions is calculated and discussed, after which the numerical simulation is used to illustrate the research results and provide some managerial suggestions for promoting tourism recovery in the post-COVID-19 period.

Building on evolutionary game theory, this study analyzes the dynamic process of stakeholders' strategies. Our research represents a step toward an improved understanding of the crisis management of tourism enterprises and governments involvement. First, shifting the focus from tourism enterprises to the stakeholders, we highlight that crisis management should be regarded as the joint responsibility of all tourism stakeholders. Second, we conduct the evolution of tourism crisis management that examines the main effect of governments involvement and tourist participation on the pandemic crisis. Third, we highlight the outstanding value of the relationship between governments and markets in responding to the pandemic, and then we discuss how this relationship evolves as the pandemic changes.

The remainder of this study is organized as follows. Section 2 presents the literature review of tourism crisis management and the application of evolutionary game theory in tourism. Section 3 introduces the evolutionary models of tourism recovery in the postCOVID-19 period. Section 4 reports the study's findings from the analysis of the proposed 
model's parameters. Section 5 offers a discussion and implications for tourism recovery. Section 6 concludes the study and proposes directions for future researches.

\section{Literature Review}

\subsection{Tourism Crises}

The impacts of crises on tourism destinations are the focus of previous research, which has mainly focused on analyzing the various crisis events' impacts on tourism demand, such as the 2008 global financial crisis, swine flu [10], earthquake disasters and terrorist attacks [11]. After the SARS epidemic in 2003, researchers began to pay attention to the impact of infectious diseases on tourism development [12]. Public health events, such as SARS [13], the bird flu [14], Ebola [15,16] and the influenza pandemic [12] have become major risk factors for tourism development through the spread of human migration activities. Due to the global spread of COVID-19 and the possible spread of the disease caused by the movement of populations across regions, national government departments have imposed unprecedented restrictions on the movement of population. Moreover, under the influence of infectious diseases, the international and regional mobility amongst populations has been curbed [17], leading to negative economic impacts. For example, due to the decline of the international tourism market in 2020, a large number of hotels in Thailand, Japan and other countries are currently on the verge of bankruptcy.

From the supply side, the occurrence of crisis events has a significant negative impact on tourism products and services. Yang et al. [18] constructed a dynamic stochastic general equilibrium (DSGE) model to analyze the impact of pandemic diseases on tourism. The analysis results of the model on COVID-19 show that tourism demand decreases with the increase of health risks. Liu et al. [19] investigated the impact of the health problems caused by the outbreak of the norovirus on cruise ships on tourists' travel decisions and found that the combined effect of the perceived threat and perceived effectiveness of the public affected their perceived safety and their travel decisions. Luo and Zhai [20] found that, as an open space for public opinion and expression, social media has increasingly become a communication channel in crisis events, leading to the secondary spread of a crisis. Given that the occurrence of crisis events can easily affect the tourism demand market, prevention and post-event management of the crisis are particularly important, especially in relation to the COVID-19 crisis discussed in this study.

Crisis management is not uncommon for tourism companies. The tourism industry is highly exposed to and highly correlated with the external environment. Given that all its components are vulnerable to environmental changes, it is also extremely vulnerable to the negative impacts of crisis events [21]. However, tourism crisis events often bring about different degrees of economic and security losses because they directly impacttourists' travel decisions and can affect the development of tourism activities [22]. In addition, although many crises that have occurred in recent years are not new due to the acceleration of globalization, the scale and duration of such events have expanded considerably. For example, for the coronavirus, the economic and social impacts of SARS are far less profound than those of COVID-19. Thus, it is particularly important to do more in-depth research relates to crisis management.

Taking the SARS epidemic management as an example, Zhang [23] evaluated government responsibility in public crisis management and concluded that, whilst paying attention to economic development, governments should also focus on public safety and public health and strive to build a complete government crisis management system. Li et al. [24] adopted the theory of planned behavior (TPB) to discuss the planned changes in travel behavior after the pandemic, and their results showed that the planned travel behavior changed significantly after the pandemic. For example, about half of the respondents planned to take a vacation six months or more once the pandemic is under control, and the vacation time will also be shortened, that is, as the representative of the demand side, tourists have shown great changes in their travel decisions in the post-pandemic period, indicating that changes in demand cannot be ignored in tourism economic recovery. Gov- 
ernments, tourism enterprises and tourists are the main stakeholders in tourism recovery after the pandemic [25]; therefore, it is necessary to analyze the dynamic evolution of the tourism industry from the perspective of stakeholders to solve the issues that stakeholders care about, which will contribute to promoting tourism recovery under the influence of the pandemic.

\subsection{Stakeholders and Tourism Recovery}

Stakeholder cooperation is an important aspect in the study of the tourism industry's response to the crisis [26,27]. Freeman [28] defined stakeholders as "any group or individual that can affect or be affected by the goals of the organization". In the tourism industry, stakeholders include individuals, groups and organizations, such as tourists, tourism enterprises, local communities and governments [29]. Leiper [30] regarded tourism stakeholders as a system composed of individuals and organizations, which carry out activities in transit and destination areas of tourism activities. The development of tourism cannot be separated from the participation of stakeholders [31], especially when facing major public crisis events.

The impacts of COVID-19 on tourism are unprecedented [32], but the economic costs brought on by these impacts on different stakeholders tend to vary. The innovation ability of tourism enterprises plays an important role in crisis recovery [2]. However, tourism enterprises may not meet the requirements of innovation due to internal and external factors [33]. In particular, a large number of small and medium-sized enterprises in the tourism industry do not have the ability to resist external risks [34]. Thus, during the postpandemic period, the tourism sector's economic recovery should not only rely on tourism enterprises themselves but should also strengthen cooperation with external systems through better macro-level policies and tourism market response. Certainly, governments are more willing to see economic stability and progress, so they are likely to actively adopt policies such as safety and health regulations, financial support and control to reduce the impact of the pandemic on tourism. Meanwhile, tourist behaviors have also changed in the post-pandemic period. Under the influence of the pandemic, tourists' choice of tourist destination will be more inclined towards domestic destinations rather than foreign countries [35], and which means that enterprises must carefully consider the expansion of the domestic tourism market when considering tourism products and services in the post-pandemic period. At the same time, people may prefer exclusivity and choose familiar tourism destinations they perceive as safe for tourism activities, which include scenic spots with fewer tourists and less congestion $[8,36]$. Moreover, there will be a gradual increase in the willingness of private cars to travel instead of public transport [37].

When stakeholders are highly involved in tourism recovery, they will have more ideas on tourism development, which in turn, can increase their participation in tourism development and jointly create value [38,39]. Governments, tourism enterprises and tourists, as major stakeholders, are involved in the recovery of tourism after the pandemic [25]. Despite the game between stakeholders in the actual tourism development, there may be a situation wherein one participant's interests are temporarily lost, but it must be admitted that, under the stakeholders' perspective, the evaluation of tourism development and the analysis of its dynamic evolution must be considered to solve the issues concerning stakeholders, thus promoting tourism sector's economic recovery from the negative impacts of the pandemic [40].

\subsection{The Application of Evolutionary Game Theory}

The evolutionary game theory originates from the idea of biological evolution and is widely applied in different fields, such as economics and social sciences [41,42]. Unlike the assumption of "perfect rational" in classical game theory, that of "limited rationality" in evolutionary game theory makes the dynamic system, whose behavior changes over time, more suitable for predicting the behavior of game participants. Thus, evolutionary game theory is in line with the actual situation. Due to its relevance to stakeholders, 
evolutionary game theory is often used to discuss the relationships amongst stakeholders. To study the dilemma of vaccination, Li et al. [43] proposed an infectious disease prediction model based on network structure and dynamic replicator and applied the evolutionary game theory framework to the population wherein each individual tries to maximize its own benefits. Wang et al. [44] studied crisis communication on social media through the model of evolutionary game theory and found that the choice of enterprises' response strategies affected the evolution of strategies pursued by Internet users. Li and Ding [45] took incidents of major animal pandemic public health as examples and used evolutionary game models to explore the restoration of social trust in public crisis management, and they found that changes in the risk of crisis incidents affected the behavior of supervisory agencies, enterprises and consumers, which in turn, led to a significant reduction in social trust in the short term.

Game players interact with other players over a period of time, and their returns are affected by the choices of other players [46]. Evolutionary game theory analyses the behaviors of participants in the tourism industry from the perspective of stakeholders [47]. $\mathrm{He}$ et al. [48] explored the government's incentive mechanism to develop sustainable tourism by constructing an evolutionary game model and made some suggestions to the government for sustainable development of tourism. Blanco et al. [49] used the evolutionary game model of tourism companies to find the relationship between green companies and regulations. The evolutionary game theory can be used effectively to analyze the relationships between stakeholders. In addition, it can help distinguish between different equilibrium states and understand the long-term dynamics of participants.

As the behaviors of tourism stakeholders under the influence of the pandemic are complex and dynamic, the future development of tourism cannot be evaluated only according to the current impact of the pandemic or by comparing similar public crisis events. Based on the behavior interaction of tourism stakeholders, applying the evolutionary game approach to the evolution analysis of tourism recovery under the influence of the pandemic can help clarify the mechanism of influence of tourism stakeholders' behaviors, provide policy recommendations for tourism recovery and minimize the impact of the pandemic on the tourism industry.

\section{Model Description}

\subsection{Background of the Model}

Starting from the game of stakeholders in tourism development, this study constructs an evolutionary game model to explore the strategies of tourism recovery in the postpandemic period. Evolutionary game theory holds that the decision subjects of games are limited rational and that they constantly learn and imitate in the process of games, thus maximizing the benefits and reaching the state of evolutionary equilibrium in this dynamic process. The evolutionary game theory abandons the assumption of "perfect rationality" of game theory and combines the thought of biological evolution, focusing on the dynamic change of strategy. That is, participants of the game will compare the fitness of the previous round with other strategies and then make a new decision. The selection of participants is a process of learning and mutation amongst groups.

ESS and replicator dynamics (RD) are the two primary concepts of the evolutionary game theory. ESS means that if all individuals in a population choose the same strategy, no mutant game can invade that strategy under the influence of natural selection; meanwhile, RD refers to the ability of individuals to constantly adjust themselves through the learning, imitation and selection of the status quo $[50,51]$. RD can be expressed by the differential equation $d_{x(t)} / d_{t}=x\left(U_{s}-\bar{U}\right)$, where $x$ denotes the proportion of strategy $s, U s$ denotes the expected fitness of strategy $s, \bar{U}$ denotes the average fitness of all strategies, and $d_{x(t)} / d_{t}$ denotes the change of strategies' proportion by time. Due to its relevance to the stakeholders, evolutionary game theory is often used to discuss the relationship between stakeholders, which helps in understanding the long-term dynamics of game participants on the basis of distinguishing different equilibrium states. 
The behaviors of tourism stakeholders under the influence of COVID-19 are complex, so the future development of tourism should not be evaluated only according to the current impact of COVID-19 or by comparing similar public crisis events. Based on the interaction of tourism stakeholders, the evolutionary game approach is applied to the evolutionary analysis of tourism recovery under the influence of COVID-19, which is helpful in clarifying the influencing mechanism of stakeholders' behavior. Specifically, governments are constrained by various conditions, such as the cost of policy implementation and the pressure of public opinion, tourism enterprises are oriented to pursue the maximization of economic benefits, and tourists' behaviors after the pandemic will be influenced by the "herd effect" and cautious minds. That is, the tripartite entities may all experience deviations in behaviors, which, in turn, will affect the development of the tourism industry after the pandemic, regardless of whether it will quickly recover to "higher ground", with retaliatory consumption, or whether it will stagnate or even retreat. In order to explain the behaviors of stakeholders under the influence of the pandemic in more detail, this study constructs evolutionary game models involving governments, tourism enterprises and tourists for further analysis.

It is noted that governments and tourists also interact with each other. For example, governments choose to control population flow during the pandemic and issue a travel ban. Although the control strategy aims at the demand side, it is actually transmitted to tourists through tourism enterprises. Because there are no companies that provide travel products and services at this time, such as closed scenic spots without ticket sales, travel traffic interception, etc., tourists are indirectly affected to choose no travel strategy. In addition, based on the rejuvenation of enterprises and the renewed performance of the tourism market, this study investigates the recovery of the tourism industry. Therefore, this study considers the dynamic game process, including the interior and exterior of the tourism industry.

\subsection{The Evolution Model of Stakeholders in the Post-COVID-19 Period}

\subsubsection{Model Description between Governments and Tourism Enterprises}

As COVID-19 carries the risk of spreading infection, tourism recovery is largely influenced by the relevant administrative directives of governments. Governments may actively support tourism enterprises to resume operations or suspend tourism activities due to the risk of virus transmission. Tourism enterprises, meanwhile, are more concerned about whether to maximize profits. Considering that the pandemic may rebound at any time, which means governments' policies are also changing at any time, enterprises may stick to the tourism development mode before the pandemic or seek new ways in the changeable macro-policy environment and innovate tourism products. Considering the possible interaction between governments and tourism enterprises in tourism development in the post-pandemic period, the model assumption of ESS analysis between the two is as follows.

(I) We denote $x$ as the probability of governments selecting regulation strategy and $1-x$ $(0<x<1)$ as the probability of governments selecting a non-regulation strategy. In addition, $y$ is the probability of tourism enterprises selecting innovative strategies for adapting to the pandemic, and $1-y(0<y<1)$ is the probability of choosing to maintain the traditional development pattern before the pandemic.

(II) When governments choose to implement the decision to support tourism enterprises, there will be a corresponding cost $\left(C_{1}\right)$. Tourism enterprises will be punished by governments $\left(P_{1}\right)$ when their non-compliance behavior affects safe production and operation activities, whereas they will be rewarded for initiating reform and innovation $\left(R_{2}\right)$. When enterprises choose to reform and innovate tourism products and services, the corresponding cost is $C_{3}$, and the operating income obtained is $R_{1}$. The cost for tourism enterprises not changing their minds and choosing to maintain the traditional development trajectory before the pandemic is $C_{4}$, and the operating income obtained by traditional methods is $R_{3}$. When tourism enterprises choose traditional 
methods of development, social losses, such as pollution and safety accidents, will require governments to pay corresponding governance costs $\left(C_{2}\right)$. Table 1 explains the payoff values.

Table 1. The payoff values matrix between governments and tourism enterprises.

\begin{tabular}{cccc}
\hline \multirow{2}{*}{ Game Agents and Their Strategies } & \multicolumn{2}{c}{ Tourism Enterprises } \\
\cline { 2 - 3 } & & Innovation & Traditional Development Pattern \\
\hline \multirow{2}{*}{ Governments } & Regulation & $\left(-C_{1}-R_{2},-C_{3}+R_{1}+R_{2}\right)$ & $\left(-C_{1}+P_{1}-C_{2},-C_{4}+R_{3}-P_{1}\right)$ \\
\cline { 2 - 3 } & Non-regulation & $\left(0,-C_{3}+R_{1}\right)$ & $\left(-C_{2},-C_{4}+R_{3}\right)$ \\
\hline
\end{tabular}

Here, $U_{1 G O V}$ and $U_{2 G O V}$ denote governments' expected fitness of the different selections (regulation and non-regulation, respectively), and $\bar{U}_{G O V}$ denotes the average fitness of governments. Moreover, $U_{1 C O M}$ and $U_{2 C O M}$ denote tourism enterprises' expected fitness of different selections (innovation and traditional development pattern, respectively), and $\bar{U}_{C O M}$ denotes the average fitness of tourism enterprises. We calculate the fitness of governments as follows:

$$
\begin{gathered}
U_{1 G O V}=y\left(-C_{1}-R_{2}\right)+(1-y)\left(-C_{1}+P_{1}-C_{2}\right)=-R_{2} y-C_{1}-C_{2}+P_{1}+C_{2} y-P_{1} y, \\
U_{2 G O V}=y \cdot 0+(1-y)\left(-C_{2}\right)=-C_{2}+C_{2} y,
\end{gathered}
$$

and

$$
\bar{U}_{G O V}=x\left(-R_{2} y-C_{1}-C_{2}+P_{1}+C_{2} y-P_{1} y\right)+(1-y)\left(-C_{2}+C_{2} y\right)=-R_{2} x y-C_{1} x+P_{1} x-P_{1} x y-C_{2}+C_{2} y .
$$

From Equations (1)-(3), the replicator dynamic equation of governments' selection can be expressed as

$$
F(x)=\frac{d x}{d t}=x(1-x)\left(-R_{2} y-C_{1}+P_{1}-P_{1} y\right) .
$$

Similar to the evolution process for the dynamic equation of governments, we calculate the fitness of tourism enterprises as

$$
\begin{gathered}
U_{1 \mathrm{COM}}=x\left(-C_{3}+R_{1}+R_{2}\right)+(1-x)\left(-C_{3}+R_{1}\right)=R_{2} x+R_{1}-C_{3}, \\
U_{2 \mathrm{COM}}=x\left(-C_{4}+R_{3}-P_{1}\right)+(1-x)\left(-C_{4}+R_{3}\right)=-P_{1} x+R_{3}-C_{4},
\end{gathered}
$$

and

$$
\bar{U}_{\mathrm{COM}}=y\left(R_{2} x+R_{1}-C_{3}\right)+(1-y)\left(-P_{1} x+R_{3}-C_{4}\right)=R_{2} x y+R_{1} y-C_{3} y-P_{1} x+R_{3}-C_{4}+P_{1} x y-R_{3} y+C_{4} y,
$$

From Equations (5)-(7), the replicator dynamic equation of tourism enterprises' selection can be expressed as

$$
F(y)=\frac{d y}{d t}=y(1-y)\left(R_{2} x+R_{1}-C_{3}+P_{1} x-R_{3}+C_{4}\right),
$$

\subsubsection{Model Description between Tourism Enterprises and Tourists}

Tourists, as the main receiver of tourism products and services, their attitudes can affect the development of tourism activities. Under the influence of the pandemic, tourists are more careful about the safety of tourism activities and have higher requirements for safer, more personalised tourism products. The impact of the pandemic has also given birth to cloud tourism, and surrounding tourism has attracted more attention from tourists. Thus, tourism enterprises must think about whether to make changes and innovate tourism products. Considering the possible interaction between tourism enterprises and tourists in 
the development of tourism in the post-pandemic period, the model assumption of ESS analysis between the two is as follows.

(I) We denote $y$ as the probability of tourism enterprises selecting innovative strategies for adapting to the pandemic, and $1-y(0<y<1)$ as the probability of choosing to maintain the traditional development pattern before the pandemic. The tourists strategic choice is to travel or not to travel, and the selection probabilities are given respectively by $z$ and $1-z(0<z<1)$.

(II) When enterprises choose to reform and innovate tourism products and services, the corresponding cost is $c_{1}$, and the operating income obtained is $r_{1}$, and if the tourists support getting extra income of $r_{2}$. The cost for tourism enterprises cannot change their minds and choose to maintain the traditional development trajectory before the pandemic is $c_{2}$, and the operating income obtained by traditional methods is $r_{3}$. As for tourists, the cost of the travel strategy is $c_{3}$, the additional experience benefit obtained during the enterprise innovation is $r_{4}$, and the experience benefit of the enterprise maintaining the traditional operating mode is $r_{5}$. Table 2 explains the payoff values.

Table 2. The payoff values matrix between tourism enterprises and tourists.

\begin{tabular}{lccr}
\hline \multirow{2}{*}{ Game Agents and Their Strategies } & \multicolumn{2}{c}{ Tourism Enterprise } \\
\cline { 2 - 3 } & Travel & $\left(-c_{3}+r_{4},-c_{1}+r_{1}+r_{2}\right)$ & Traditional Development Pattern \\
\hline \multirow{2}{*}{ Tourists } & No travel & $\left(0,-c_{1}+r_{1}\right)$ & $\left(-c_{3}+r_{5},-c_{2}+r_{3}\right)$ \\
\cline { 2 - 3 } & & $\left(0,-c_{2}+r_{3}\right)$ \\
\hline
\end{tabular}

Here, $U_{1 T O U}$ and $U_{2 T O U}$ denote the tourists' expected fitness of the different selections (travel and no travel, respectively), and $\bar{U}_{T O U}$ denotes the average fitness of tourists. Moreover, $U_{1 C O M}$ and $U_{2 C O M}$ denote tourism enterprises' expected fitness of different selections (innovation and traditional development pattern, respectively), and $\bar{U}_{\mathrm{COM}}$ denotes the average fitness of tourism enterprises. Then, the dynamic differential equations of replication for the strategic choices of tourism enterprises and tourists can be expressed as

$$
\begin{gathered}
F(y)=y(1-y)\left(r_{2} z-c_{1}+r_{1}+c_{2}-r_{3}\right), \\
F(z)=z(1-z)\left(r_{4} y-c_{3}+r_{5}-r_{5} y\right) .
\end{gathered}
$$

\subsubsection{Model Description amongst Tourism Enterprises}

The fluctuation of tourism demand under the development of the pandemic has a significant impact on tourism enterprises. Thus, how should tourism enterprises, including travel agencies, hotels, catering and transportation, deal with the impact of the pandemic? Is it more conducive to the rapid recovery of tourism to "fight against each other" or to "stick together"? After analyzing the interactions between tourism companies and other stakeholders (governments and tourists), this study further explores the impact of strategic interaction amongst tourism enterprises on tourism recovery. Considering the possible interaction amongst tourism enterprises in the development of tourism in the post-pandemic period, the model assumption of ESS analysis between the two is as follows.

(I) The enterprise is the subject of limited rationality, and the strategic choice of the participants of the game (assuming tourism enterprise A and tourism enterprise B) can either be cooperation or non-cooperation. The probability of enterprise A choosing cooperative strategy is $m$, and the probability of adopting non-cooperative strategy is $1-m$, where $(0<m<1)$. The probabilities of enterprise $\mathrm{B}$ choosing cooperation and non-cooperation strategies are $n$ and $1-n$, respectively, where $(0<n<1)$.

(II) When both participants choose the non-cooperative strategy, their respective benefits are $R_{a}$ and $R_{b}$. When both participants choose the cooperation strategy, the incremental benefit they can get is $\Delta$, and $\delta_{i}(i=a, b)$ is the change in their respective returns 
when the two strategy choices are opposite. That is, the non-cooperative enterprise can obtain an incremental income of $\delta_{i}(i=a, b)$, whilst the enterprise that adopts the cooperation strategy produces a loss of $\delta_{i}(i=a, b)$, assuming that $\delta_{i}<\Delta$. Table 3 explains the payoff values.

Table 3. The payoff values matrix among tourism enterprises.

\begin{tabular}{cccc}
\hline \multirow{2}{*}{$\begin{array}{c}\text { Game Agents } \\
\text { and Their Strategies }\end{array}$} & \multicolumn{2}{c}{ Tourism Enterprise B } \\
\cline { 2 - 4 } & Cooperation & $\left(R_{a}+\Delta, R_{b}+\Delta\right)$ & $\left(R_{a}-\delta_{a}, R_{b}+\delta_{b}\right)$ \\
\hline \multirow{2}{*}{$\begin{array}{c}\text { Tourism } \\
\text { Enterprise A }\end{array}$} & Non-cooperation & $\left(R_{a}+\delta_{a}, R_{b}-\delta_{b}\right)$ & $\left(R_{a}, R_{b}\right)$ \\
\hline
\end{tabular}

Then, the dynamic differential equations of replication for the strategic choices of tourism enterprise $\mathrm{A}$ and $\mathrm{B}$ are as follows:

$$
\begin{gathered}
F(m)=m(1-m)\left(\Delta n-\delta_{a}\right), \\
F(n)=n(1-n)\left(\Delta m-\delta_{b}\right) .
\end{gathered}
$$

\section{Model Solutions}

\subsection{ESS Analysis amongst Stakeholders}

Firstly, by analyzing the differential equations, we obtain five local equilibrium points. Let differential Equations (4) and (8) equal 0, the equilibrium points of the system composed of governments and tourism enterprises are given by

$$
(0,0),(0,1),(1,0),(1,1) \text { and }\left(\frac{R_{3}-C_{4}-R_{1}+C_{3}}{R_{2}+P_{1}}, \frac{P_{1}-C_{1}}{R_{2}+P_{1}}\right) .
$$

The stability of the equilibrium point can be obtained by the local stability analysis of the Jacobian matrix of the system [46]. Taking the partial derivatives of $x$ and $y$ based on differential Equations (4) and (8), in turn, we can express the Jacobian as

$$
J=\left[\begin{array}{c}
(1-2 x)\left(-R_{2} y-C_{1}+P_{1}-P_{1} y\right),-x(1-x)\left(R_{2}+P_{1}\right) \\
y(1-y)\left(R_{2}+P_{1}\right),(1-2 y)\left(R_{2} x+R_{1}-C_{3}+P_{1} x-R_{3}+C_{4}\right)
\end{array}\right] .
$$

Table 4 shows the stability results of equilibrium points between governments and tourism enterprises.

Table 4. Local stability analysis of the equilibrium points (I).

\begin{tabular}{ccccc}
\hline Equilibrium Point & $\operatorname{det}(J)$ & $\operatorname{tr}(J)$ & Local Stability & Conditions \\
\hline$(0,0)$ & + & - & ESS & $P_{1}<C_{1}, R_{1}-C_{3}<R_{3}-C_{4}$ \\
\hline$(0,1)$ & + & - & ESS & $R_{1}-C_{3}>R_{3}-C_{4}$ \\
\hline$(1,0)$ & + & - & ESS & $P_{1}>C_{1}, R_{2}+P_{1}+R_{1}-C_{3}<R_{3}-C_{4}$ \\
\hline$(1,1)$ & - & $/$ & Saddle point & $/$ \\
\hline$\left(\frac{R_{3}-C_{4}-R_{1}+C_{3}}{R_{2}+P_{1}}, \frac{P_{1}-C_{1}}{R_{2}+P_{1}}\right)$ & $/$ & 0 & $/$ & $/$ \\
\hline
\end{tabular}

Secondly, the equilibrium points of the system composed of tourism enterprises and tourists are $(0,0),(0,1),(1,0),(1,1)$ and $\left(\frac{r_{5}-c_{3}}{r_{5}-r_{4}}, \frac{r_{1}-c_{1}-r_{3}+c_{2}}{r_{2}}\right)$. Taking the partial 
derivatives of y and $z$ based on differential Equations (9) and (10), in turn, we can express the Jacobian as

$$
J=\left[\begin{array}{c}
(1-2 y)\left(r_{2} z-c_{1}+r_{1}+c_{2}-r_{3}\right), y(1-y) r_{2} \\
z(1-z)\left(r_{4}-r_{5}\right),(1-2 z)\left(r_{4} y-c_{3}+r_{5}-r_{5} y\right)
\end{array}\right]
$$

Table 5 shows the stability results of equilibrium points between tourism enterprises and tourists.

Table 5. Local stability analysis of the equilibrium points (II).

\begin{tabular}{|c|c|c|c|c|}
\hline Equilibrium Point & $\operatorname{det}(J)$ & $\operatorname{tr}(J)$ & Local Stability & Conditions \\
\hline$(0,0)$ & + & - & ESS & $r_{1}-c_{1}<r_{3}-c_{2}, r_{5}<c_{3}$ \\
\hline$(0,1)$ & + & - & ESS & $r_{2}+r_{1}-c_{1}<r_{3}-c_{2}, r_{5}>c_{3}$ \\
\hline$(1,0)$ & + & - & ESS & $r_{1}-c_{1}>r_{3}-c_{2}, r_{4}<c_{3}$ \\
\hline$(1,1)$ & + & - & ESS & $r_{2}+r_{1}-c_{1}>r_{3}-c_{2}, r_{4}>c_{3}$ \\
\hline$\left(\frac{r_{5}-c_{3}}{r_{5}-r_{4}}, \frac{r_{1}-c_{1}-r_{3}+c_{2}}{r_{2}}\right)$ & / & / & Instability & / \\
\hline
\end{tabular}

Thirdly, the equilibrium points of the system composed of Equations (11) and (12) are $(0,0),(0,1),(1,0),(1,1)$ and $\left(\frac{\delta_{b}}{\Delta}, \frac{\delta_{a}}{\Delta}\right)$. Taking the partial derivatives of $m$ and $n$ based on differential Equations (11) and (12), in turn, we can express the Jacobian as

$$
J=\left[\begin{array}{c}
(1-2 m)\left(\Delta n-\delta_{a}\right), m(1-m) \Delta \\
n(1-n) \Delta,(1-2 n)\left(\Delta m-\delta_{b}\right)
\end{array}\right]
$$

Table 6 shows the stability results of equilibrium points amongst tourism enterprises.

Table 6. Local stability analysis of the equilibrium points (III).

\begin{tabular}{cccc}
\hline Equilibrium Point & $\operatorname{det}(J)$ & $\boldsymbol{t r}(J)$ & Local Stability \\
\hline$(0,0)$ & + & - & ESS \\
\hline$(0,1)$ & + & + & Instability \\
\hline$(1,0)$ & + & + & Instability \\
\hline$(1,1)$ & + & 0 & ESS \\
\hline$\left(\frac{\delta_{b}}{\Delta}, \frac{\delta_{a}}{\Delta}\right)$ & - & Saddle point
\end{tabular}

Figure 2 shows the convergence of stakeholders' strategies amongst governments, tourists and tourism enterprises. 


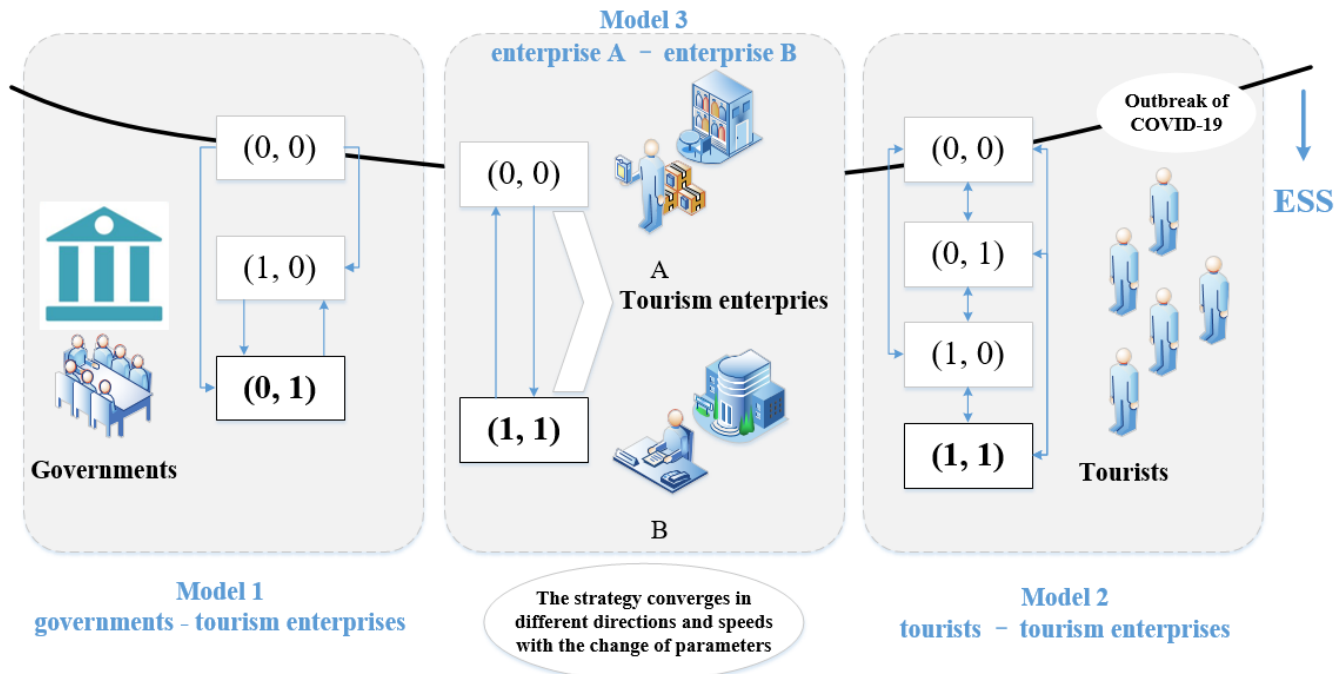

Figure 2. The convergence of stakeholders' strategies in the post-COVID-19 period.

\subsection{Strategy Stability Analysis}

The stability analysis of the Jacobian equilibrium point proves whether or not the dynamic evolution system is stable. When the Jacobian matrix satisfies the condition that the determinant $(J)$ is greater than 0 and the trace $(J)$ is less than 0 , the method achieves evolutionary system stability [46]; that is, convergence has local stability characteristics. It can be seen from Table 4 to Table 6 that the stable strategy changes with the circumstances.

The first is the dynamic game model between governments and tourism enterprises. At the equilibrium point $\left(\frac{R_{3}-C_{4}-R_{1}+C_{3}}{R_{2}+P_{1}}, \frac{P_{1}-C_{1}}{R_{2}+P_{1}}\right), \operatorname{tr}(J)=0$, but this point is not the ESS. Combining the different value ranges of the parameters for further discussion, amongst them, $(0,0),(0,1)$ and $(1,0)$ are the evolutionary stable strategies of the dynamic system, corresponding to the three strategies, namely, (non-regulation, traditional development pattern), (non-regulation, innovation) and (regulation, traditional development pattern). The remaining two local stable points indicate that the system is in a temporary stable state; once there is a disturbance factor, it will deviate [52]. In order to promote the post-pandemic tourism recovery, $R_{1}-C_{3}>R_{3}-C_{4}$ should be realized. This means that when the income of the traditional development mode of enterprises is less than that of innovation, enterprises will actively make changes and actively integrate into the innovation of tourism activities after the pandemic. In addition, $(0,1)$ is the ideal equilibrium point, which does not mean the absence of governments' regulation, but over time, governments have provided support for the resumption of tourism activities, such as medical follow-ups and vouchers for consumption. Furthermore, governments realize that there is no need to continue to regulate and that both governments and tourism enterprises would achieve a win-win situation to maximize their respective interests.

Secondly, the attitudes and behaviors of tourists after the pandemic affect the tourism economic recovery process. In the dynamic model of tourism enterprises and tourists, $(0,0),(0,1),(1,0)$ and $(1,1)$ are ESS under different conditions, which means that, in the interaction between tourism enterprises and tourists, there are more local stability points. Tourists are more random and changeable, and they take into account the benefits they have gained from tourism activities [24], such as security, experience, happiness and other factors. When tourists have a high sense of acquiring new tourism experience products provided by enterprises, namely, $r_{4}>c_{3}$, they recognise the measures taken by enterprises to deal with the pandemic and actively participate in tourism economic recovery during the post-pandemic period. When the traditional products can also bring them a higher sense of acquisition, they will choose the original tourism products. In other words, tourism enterprises are more of the groups pursuing profit maximization, and their production 
and operation are affected by the rapidly changing market. Support from tourists directly affects whether tourism enterprises can reduce losses and achieve business innovation under the impact of the pandemic. Therefore, the decision of tourists is very important. In this model, the ideal state of ESS is $(1,1)$, that is, tourism enterprises choose innovative development and actively adapt to the changes brought about by the pandemic, and tourists also actively support the products and services of tourism enterprises after the pandemic, at this time both participants actually maximize their revenue.

Finally, in terms of the game model amongst tourism enterprises, $(0,0)$ and $(1,1)$ have local stability (Table 6); that is, tourism enterprises will choose cooperative strategies or non-cooperative strategies at the same time. The evolutionary game process amongst enterprises is shown in Figure 3. As can be seen, the polyline formed by A, D and B (A and $B$ are unstable points, $D$ is a saddle point) represents the division of different convergence states. Amongst them, the cooperation strategy converges to the upper right of the polyline $\mathrm{ADB}$ (namely, the $\mathrm{ADBC}$ region), and the non-cooperative policy converges to the lower left of the broken $\mathrm{ADB}$ (ABDO region). In order to promote the transformation of enterprise strategy selection from $(0,0)$ to $(1,1)$, so as to expand the cooperative strategy area (ADBC) as far as possible, we turn to the following equation:

$$
S_{A D B C}=S_{A C D}+S_{B C D}=\frac{1}{2} A C \cdot h_{A C D}+\frac{1}{2} B C \cdot h_{B C D}=1-\frac{1}{2}\left(\frac{\delta_{b}}{\Delta}+\frac{\delta_{a}}{\Delta}\right)=1-\frac{\delta_{b}+\delta_{a}}{2 \Delta} .
$$

After the partial derivative treatment, $\frac{\partial S_{A D B C}}{\partial \delta_{a}}=-\frac{1}{2 \Delta}<0, \frac{\partial S_{A D B C}}{\partial \delta_{b}}=-\frac{1}{2 \Delta}<0$, $\frac{\partial S_{A D B C}}{\partial \Delta}=\frac{\delta_{a}+\delta_{b}}{2 \Delta^{2}}>0$. That is, incremental revenues $\Delta$ and $\delta_{i}(i=a, b)$ are important factors affecting tourism enterprises' strategy change. As can be seen from Figure 3 , in order to promote cooperation between enterprises, promote tourism recovery and improve the anti-risk capability of tourism enterprises, $\delta_{i}(i=a, b)$ should be reduced as much as possible, and $\Delta$ should be increased.

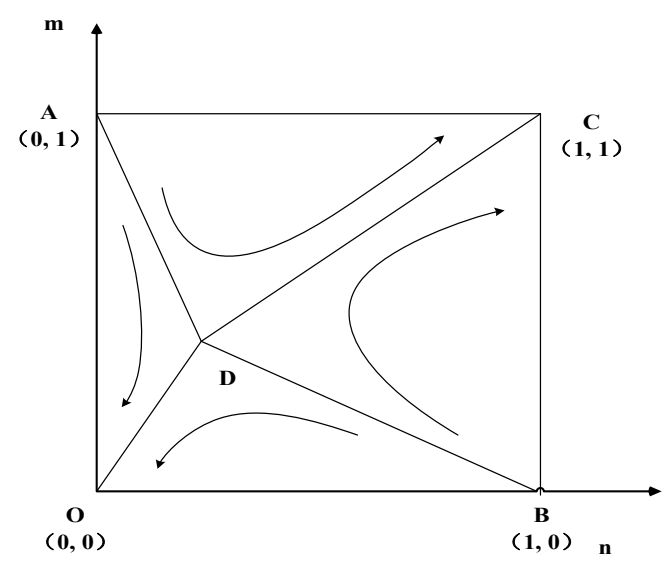

Figure 3. A dynamic replication phase diagram of evolutionary game amongst tourism enterprises.

\section{Discussion}

This study uses evolutionary game theory to explain the interaction process of key stakeholders in tourism activities after the outbreak of the COVID-19 pandemic. The cooperation between tourism enterprises and the behaviors of interest groups (governments and tourists) are included in the evolutionary game model. Below, we discuss the main findings and implications.

\subsection{Discussion of Model Results}

\subsubsection{Model Result between Governments and Tourism Enterprises}

In terms of the interaction between governments and tourism enterprises (Table 4), when the benefits of tourism enterprises after changing their innovative development 
ideas are greater than those of traditional ways, tourism enterprises will choose innovative development ideas regardless of governments' regulation, therefore, in this case, the government authorities do not need to carry out supervision and policy support. This finding shows that when the outbreak of the pandemic just happened due to the lack of relevant security measures and systems as well as the insufficient allocation of technology and human resources and other factors, the competent government departments could not formulate effective control measures in a timely manner. With the pandemic gradually under control, tourism enterprises began to seek development breakthroughs. Governments also successively implemented the intervention and auxiliary measures to guide and support the recovery of enterprises, such as tax reduction [53]. For those enterprises with hidden risks of safe operation and non-compliant operation procedures, certain penalties should be given to promote enterprises to try to break through innovation. However, the development and innovation of tourism products and services is a complex process, and the pandemic situation also has local fluctuations and rebound. Therefore, in the post-pandemic period, tourism markets will present the situation of governments' regulation or no regulation and the coexistence of enterprise innovation and traditional business mode. That is, at different stages of pandemic development, governments need to carry out targeted regulation and support in order to realize the innovative development of tourism enterprises without governments' regulation. Tourism enterprises need to take the pandemic as a challenge, adapt to the changes brought by the pandemic. Building on the demand of risk aversion and crisis management after pandemics, augmented reality could be a critical flue for boosting tourism development [54]. There are some existing travel applications, such as the existing travel applications cloud tourism, live video streaming of tourism products, which provided a reference for the extensive applications of augmented reality in the future tourism industry. Moreover, the widespread use of these products also proves that augmented reality-based tourism has the potential to become the mainstream of post-pandemic tourism.

In order to more intuitively explain the stability of strategy evolution between governments and tourism enterprises, this study takes tourism enterprises as an example, assigns the parameters and simulates the dynamic evolution process of its strategy through MATLAB R2016b software. Assuming that $C_{1}=3, C_{2}=6, C_{3}=7, C_{4}=5, R_{2}=3$, $R_{3}=16$ and $P_{1}=5$, the influences of income changes brought by enterprise innovation development ideas on the strategy selection of tourism enterprises are analysed. Figure $4 \mathrm{a}$ shows the change of the development of tourism enterprises' strategy selection over time when $R_{1}=13, R_{1}-C_{3}<R_{3}-C_{4}$, then $x^{\prime}=0.625$; if $x>x^{\prime}$, the desirable $x=0.7$, and the replication dynamic equation of the tourism enterprise is $y=0.6 y(1-y)$. When governments choose to control with $70 \%$ probability, under different initial probabilities of tourism enterprises choosing reform and innovation development strategies, the probability of tourism enterprises choosing to abandon the traditional business mode converges to 1 . Moreover, the higher the initial probability, the faster the convergence speed. If $x<x^{\prime}$, the desirable $x=0.4$, and the replication dynamic equation of the tourism enterprise is $y=-1.8 y(1-y)$, the change of the development of tourism enterprises' strategy selection over time is shown in Figure 4b. Under different initial probabilities of tourism enterprises choosing reform and innovation development strategies, the probability of tourism enterprises deciding to give up traditional business methods converges to 0; moreover, the smaller the probability value of governments' strategy convergence to non-regulation, the faster the convergence speed of tourism enterprises choosing the traditional business mode, which completely states that both governments and enterprises are in a state of constant evolution of the strategy. When $R_{1}=20$, that is, $R_{1}-C_{3}>R_{3}-C_{4}$, the benefits brought by reform and innovation exceed those of the traditional business mode, and the reform and innovation strategy becomes the best strategy for enterprises. At this point, governments will choose not to regulate, and (non-regulation, innovation) becomes an ESS. That is, when enterprises carry out innovation independently under the regulation 
of the market mechanism and turn the challenge of the pandemic into the driving force, governments will shift their focus of work, and the tourism market will regain its vitality.

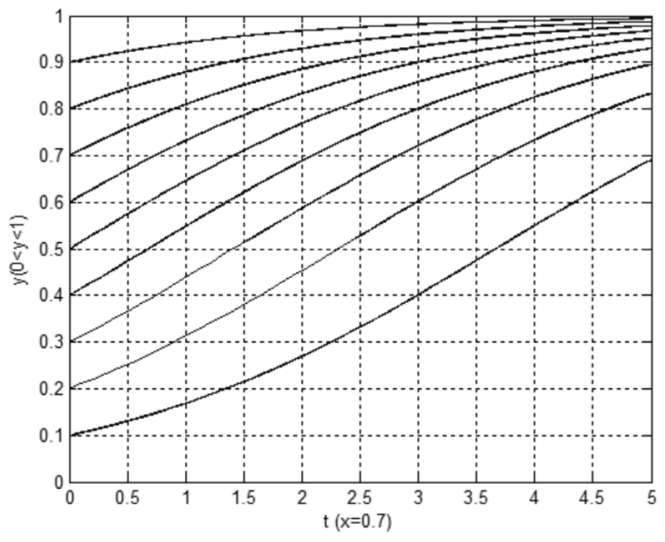

(a)

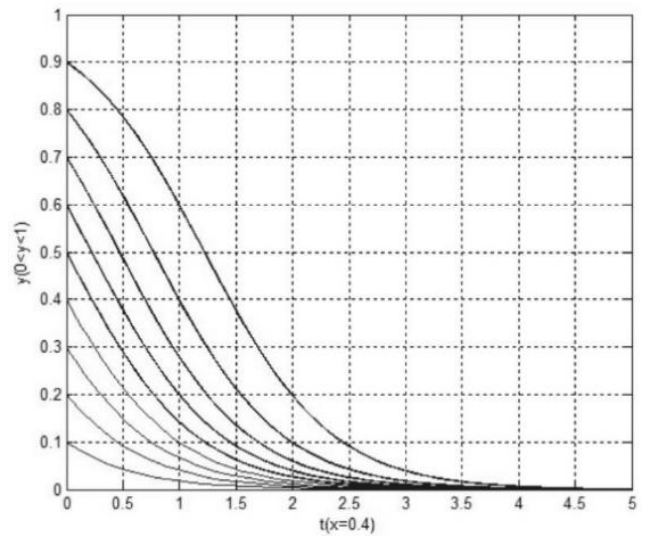

(b)

Figure 4. Dynamic evolution of strategy selection of tourism enterprises over time, when $(\mathbf{a}) \mathrm{x}=0.7$ and $(\mathbf{b}) \mathrm{x}=0.4$.

\subsubsection{Model Result between Tourism Enterprises and Tourists}

In the interactive game model between tourists and tourism enterprises, $(0,0),(0,1)$, $(1,0)$ and $(1,1)$ are the evolutionary stability strategies of the system (Table 5$)$. Under the impact of the pandemic, the unstable factors of the tourism business have increased, and enterprises are faced with different influencing factors at different stages of the pandemic. When the pandemic breaks out and is not effectively controlled, population flow is under control, and it is difficult for tourism companies to carry out production and operation activities. In turn, this situation directly impacts tourism development, and a $(0,0)$ convergence trend occurs. With the follow-up of medical measures and the advancement of governments' macro-control, the pandemic has now been controlled to a certain extent, and there has been no large-scale spread. At this stage, while the pandemic has been controlled to some extent, tourists are choosing fewer trips for safety demand [18]. Therefore, tourism enterprises should adjust themselves, and there is no need to launch tourism products and services immediately. Instead, they should appease tourists who purchased tourism products and services before and during the pandemic through various initiatives, such as timely refund and exchange of tickets, the timely reply of enterprise network customer service, etc. that is, taking social responsibility can help tourism enterprises establish a better corporate image. With the end of the pandemic, many demands will be generated, and tourists' demand for tourism products and services is expected to change. For example, tourists are more likely to consider the geographical location of the scenic spot, whether the transportation is safe, as well as whether some tourism products (e.g., cruise tourism products) should be purchased [55]. At this point, it is necessary for tourism enterprises to think about the change of future tourism mode and provide more high-quality and personalised tourism products and services, such as self-guided tours, family tours, RV tours and surrounding tours, supporting more fresh attractions and travel confidence for tourists $[54,56]$, In short, it promotes the evolutionary game converges towards $(1,1)$.

\subsubsection{Model Results amongst Tourism Enterprises}

This pandemic would lead to an inevitable reshuffling and transformation of the tourism industry [57]. From the resource side, the cost burden and low benefit return brought by multiple agents and second-hand dealers will lead to huge challenges to the development of tourism enterprises. Whether tourism enterprises adopt cooperation or competition will certainly affect their future after the pandemic. Specifically, the entire industry chain of tourism has been greatly impacted by the pandemic, including trans- 
portation, hotel industry, scenic spots, etc., which involve all aspects of tourism, food, accommodation, transportation, travel, shopping and entertainment. Promoting cooperation among enterprises and striving for the evolution of the game between enterprises from $(0,0)$ to $(1,1)$ is not only the key to deal with the survival crisis of enterprises at present but also an important demand for enhancing the anti-risk ability of tourism enterprises, which is valuable for improving crisis management in the long run [58].

Tourism enterprises are participants with limited rationality, and they will analyse and judge the differences caused by strategic choices. Specifically, when the income distribution of cooperation amongst enterprises can meet their development expectations, cooperative behaviours will occur. Furthermore, if the two sides of the enterprise have similar levels of capability, they will maximise the cooperation to find the proper innovation path. A large number of small and micro-enterprises in the tourism industry will inevitably be impacted by the pandemic; meanwhile, due to the serious homogeneity of tourism products, innovation can be easily imitated. Therefore, in order to increase cooperation revenue, tourism enterprises can also seek cross-border cooperation, such as "tourism + health care", "tourism + science popularisation" and "tourism + Internet", in order to change the traditional way of tourism development, turn challenges into opportunities and realise tourism recovery in the post-pandemic period.

\subsection{Theoretical Implications}

This study discusses the interaction process of stakeholders in the post-pandemic period and adopts evolutionary game theory to analyse the dynamic change process of the strategy. The study shows that the behaviours of governments, enterprises and tourists have an important impact on the speed and direction of tourism recovery in the post-pandemic period. The study makes the following theoretical contributions.

In terms of concepts and methods, our findings enrich the literature on tourism crisis management, especially the research on tourism restoration, by using the evolutionary game method to construct the interactive behaviours amongst stakeholders. By adopting this method, the limited rationality of stakeholders and the long-term dynamic evolution reality of tourism restoration are fully considered.

Our results also provide new ideas for understanding tourism recovery and tourism crisis management after public health events. Upon comparing our research results with previous studies $[19,59]$, we find that no study has provided an overall analysis of the conditions of its onset and the dynamic process of tourism restoration [60]. It must be pointed out that we regard tourism recovery after the pandemic as an integrated system and analyse the impact on tourism recovery after the pandemic through the interactions amongst stakeholders at different times and spaces. Further, we believe that such a system presents a more macroscopic and comprehensive dynamic evolution process. Amongst them, governments' control and changes in tourists' consumption behaviour during the post-pandemic period are the key points that must be emphasised in tourism recovery.

By comparing the results of the game analysis with those of the government involved in tourism, previous studies suggested that the role of governments should be reconsidered in the development of tourism, and the involvement in tourism development should be coordinated [61-63]. Our findings add to the literature on government involvement in tourism development. Given that market forces are inherently unstable [64], government control is essential, especially when a public health incident with a large spread occurs. Moreover, government control is conducive to allocating resources when a pandemic occurs, helping control population flow and preventing the large-scale spread of the pandemic [65]. However, as the pandemic is effectively controlled, governments' will gradually withdraw the bans, and the tourism market will recovery itself, which, in turn, will help improve the anti-risk ability of tourism enterprises. Overall, this study complements previous findings by providing a much more detailed examination of evolutionary game theory. 


\subsection{Managerial Implications}

In practice, the research results can be used by local authorities and tourism organisations to formulate policies to cope with the crisis and design appropriate tourism recovery strategies. The findings may also provide bases upon which local authorities in destination cities can take regulatory and intervention measures to reduce losses during or after a crisis.

Several managerial implications can be drawn from this study. The impact of crisis events, such as public health events, natural disasters and public safety events, on the tourism industry with fragile attributes is self-evident. In particular, the impact of major public health events on tourism development is more obvious in terms of the frequency of population mobility in these modern times. Therefore, how to understand its impact, adopt active coping strategies and minimise the negative impact on the tourism industry are major issues currently faced by the stakeholders. Under the impact of the pandemic, the recovery and operation of tourism is not only the task of the tourism industry but also the concern of the whole society. Through the analysis of the evolutionary game model, the important roles of stakeholders in the recovery of tourism after the pandemic are further clarified. The results support the viewpoint that the strategies of governments, tourism enterprises and tourists in the post-pandemic time are constantly changing. Due to the limited rationality, their strategies are not optimal. However, they keep learning, improving and seeking the maximization of benefits at different stages. The results develop the understanding of the long-term dynamics of stakeholders' decisions in the tourism restoration process and also contribute new insight for subjects facing varying degrees of the impact of the pandemic, as shown in Figure 5. With the development and changes of the pandemic, reducing the impact of the pandemic on tourism requires the joint efforts of stakeholders [27].

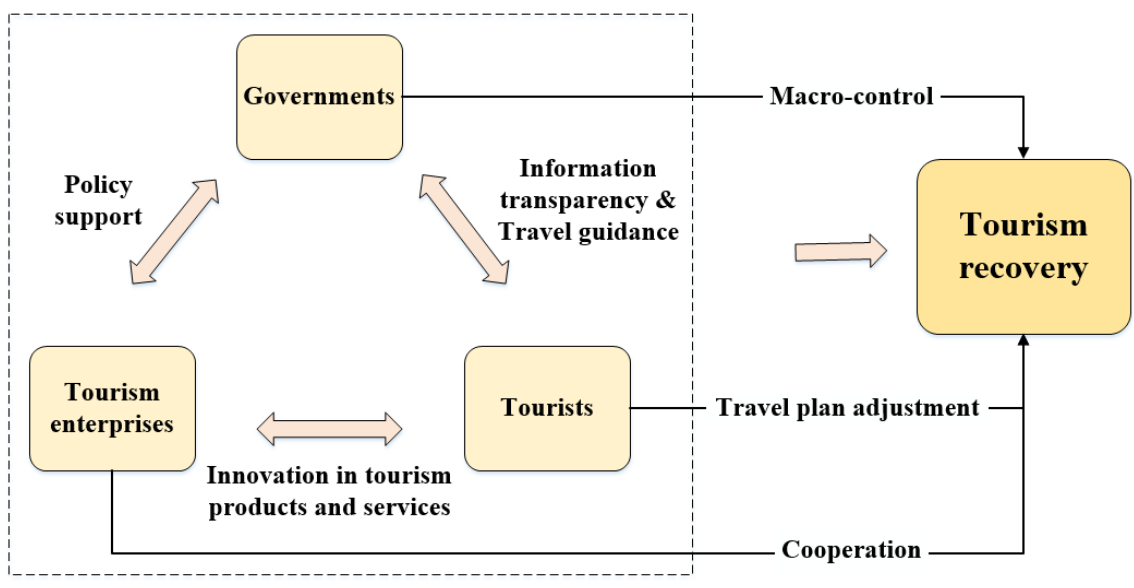

Figure 5. Stakeholders' interaction in tourism recovery.

Firstly, this study confirms that governments' regulation is essential during the peak and fluctuating stages of the pandemic development because it can alleviate the fluctuation of strategies between tourism enterprises and tourists and stabilise the market situation. In the post-pandemic period, governments must implement corresponding policies to support, promote the reform and innovation development ideas of tourism enterprises and boost the recovery of the tourism industry [65]. Under the impact of the pandemic, the tourism demand market has shrunk sharply, and the most urgent task for tourism enterprises is to obtain cash flow to survive. Therefore, enterprises should actively seek government support and establish a benign interaction with governments, such as interestfree or discounted loans, quality deposit refund, corresponding tax reduction, tax refund, fund grants, subsidies, financial support, as well as providing financial services for distressed enterprises. Once the pandemic is under control, governments should actively consider formulating a plan to promote post-pandemic tourism revitalisation, which, in turn, can actively support and rescue the tourism industry. Such a plan could include 
rewarding the tourism industry employees who have made contributions, innovating publicity ideas and strengthening publicity efforts. Other programs may include increasing tourism development funds and giving more financial support to stimulate consumption and promote economic development [66]. For example, promotion activities for tourism enterprises and scenic spots can be organised in stages, such as halving fees for scenic spots and price cuts for restaurants, hotels and retail stores. Governments can offer discounts and safety information to tourists through price subsidies and daily pandemic notifications and encourage tourists to develop tourism activities that are close to the outdoors and natural elements, such as self-driving tours, outdoor camp tours and study tours.

Furthermore, what needs attention is that emergency public safety incidents like COVID-19 will have an impact on the orderly development of the tourism industry. In order to improve governments' ability to respond, it is necessary to incorporate public tourism safety planning into governments' work content, implement emergency plans, improve the overall sanitation of the tourism environment and enhance the safety of tourists (e.g., travel toilets should be equipped with necessary consumables, including toilet paper, disinfectant, etc.). In reality, governments of various countries have already responded to the pandemic in similar ways. In fact, of the 220 countries and regions analysed in the UNWTO report on tourism recovery after the pandemic, 167 countries reported specific measures to reduce the impact of the crisis and speed up recovery. Amongst them, more than 144 countries have adopted fiscal and monetary policies, and 100 countries have implemented policies to support employment and training [3].

Secondly, at different stages of pandemic development, tourists' decisions will directly affect the market acceptance of tourism products and services, resulting in an important link in tourism recovery. From the evolutionary game analysis of tourists and tourism enterprises, we find that the strategic choice of tourists (to travel or not to travel) has local stability, which depends on the income of tourists and tourism enterprises in different situations. Before the pandemic is resolved, it may be difficult for tourism enterprises to carry out tourism activities. Thus, in order to reduce the impact of the pandemic, population mobility must be reduced. Therefore, as to tourists, the best strategy at this time is to choose not to travel, reduce losses and ensure safety. Furthermore, from the perspective of tourists, what the pandemic brings to tourists is only the difference in a travel time selection. The tourism market is experiencing a temporary "repression", and it will not be extinct even under the influence of the pandemic [55]. Therefore, in the "gap period", firstly, tourism enterprises need to think about the changes of tourism demand after the pandemic and prepare for the new requirements of tourism products and services in the post-pandemic market with a positive attitude. Secondly, tourism enterprises should maintain interaction with the tourism market. In the post-pandemic period, tourists' demands and behaviors have changed greatly. Tourism enterprises need to actively address the impact of market changes on their business operations.

Finally, through the evolutionary game model amongst tourism enterprises, we find that although tourism enterprises are competing with one another, from the perspective of a "win-win" strategy, the tourism enterprises' choice of cooperation strategy is undoubtedly the best. In particular, there are a large number of small and medium-sized enterprises in the industry, and the homogeneity of tourism products is relatively serious. Therefore, innovation and development can be efficiently achieved via cooperation among enterprises [67]. Under the impact of the pandemic, the new business model will affect the original tourism pattern [2]; thus, tourism enterprises need to seek cooperation, not only amongst similar enterprises but also in terms of cross-border cooperation. In addition, tourism enterprises can discover market opportunities, create new products, improve existing products and increase the added value of tourism products and services by allowing tourists to participate in value co-creation. This not only caters to the changes in the demand market under the impact of the pandemic but also enables tourists to gain a sense of accomplishment and unique experience by participating in value co-creation, which also brings about positive interaction to tourism recovery. 


\section{Conclusions, Limitations and Directions for Future Research}

This study combines game theory and evolutionary theory, which abandons the assumption of "perfect rationality" and holds that participants are "limited rational", which is more in line with the realistic tourism environment. In addition, the fluctuations and rebounds of COVID-19 cases occur since the different pandemic prevention and control measures in different locations in the post-pandemic period. The persistence of the longterm impacts of COVID-19 is the scenario we are facing in the tourism recovery process in the post-pandemic time. Building on the above reality, this study analyses the interactive behaviors of stakeholders and contributes insights on how to transform such behaviors to promote tourism recovery. The analysis shows that governments' emergency treatment and support for enterprises can help reduce the negative impact of the pandemic on tourism, and tourists' decision-making behaviour is of great significance to the innovation and breakthrough of the tourism industry after the pandemic. As suppliers of tourism products and services, tourism enterprises also need to learn to stay together in the face of the pandemic and seek positive cooperation, which will help them recover quickly. Just as the SARS in 2003 promoted the development of the Internet, the popularisation of science and technology and the diffusion of innovation, in the post-COVID-19 period, the rebound of tourism demand will "force" the high-quality development of tourism and the provision of high added value and personalised tourism products and services. Moreover, with the development and promotion of Internet technology, a variety of new tourism consumption patterns and supply methods will even be formed, thus improving the overall efficiency of tourism enterprises and reducing tangible costs.

This study has the following limitations. Firstly, the game model and simulation analysis prove the dynamic process of tourism recovery in the post-pandemic period from the perspective of assumptions. The parameter assumptions set by the model in this study focus on the economic consequences brought by different decisions from the perspective of stakeholders' interaction. Thus, future works should use statistical data from authoritative institutions or combine this with other methods (interview or questionnaire) to verify the results of this model and promote its practical application. Secondly, although there are inherent differences amongst various stakeholders in tourism development, this study is a macro-analysis of the recovery of tourism in the post-pandemic period. Future research can also be based on the inherent difference of stakeholders to verify the result of the evolutionary game model, such as the individual differences of tourists, tourism enterprise scale and the subdivision of industry difference, etc. Moreover, because the development of tourism is closely related to the regional economy, future studies can also consider regional differences, such as the administrative ability of governments to deal with local pandemic fluctuations.

Author Contributions: Conceptualization, H.Y., H.W. and M.W.; methodology, H.W.; software, H.W.; validation, H.Y. and H.W.; formal analysis, H.Y.; investigation, H.W.; resources, H.Y.; data curation, H.W.; writing — original draft preparation, H.W. and M.W.; writing—review and editing, H.Y. and H.W.; visualization, H.W.; supervision, H.Y.; project administration, H.Y.; funding acquisition, H.Y. All authors have read and agreed to the published version of the manuscript.

Funding: This research was funded by the Development Path of Promoting the High-Quality Integration of "Cultural Tourism + Multi Industry" in Guizhou Province During the Period of the 14th-Five-Year Plan (grant number 20GZZB04) and Research on the Integration Development of Liquor Culture and Tourism (grant number A2020004).

Institutional Review Board Statement: Not applicable.

Informed Consent Statement: Not applicable.

Data Availability Statement: Data sharing not applicable.

Conflicts of Interest: The authors declare no conflict of interest. 


\section{References}

1. Yang, R.; Du, G.; Duan, Z.; Du, M.; Miao, X.; Tang, Y. Knowledge System Analysis on Emergency Management of Public Health Emergencies. Sustainability 2020, 12, 4410. [CrossRef]

2. Zenker, S.; Kock, F. The coronavirus pandemic-A critical discussion of a tourism research agenda. Tour. Manag. 2020, 81, 104164. [CrossRef]

3. How Are Countries Supporting Tourism Recovery? Available online: https://webunwto.s3.eu-west-1.amazonaws.com/s3fspublic/2020-06/BFN_V4.pdf (accessed on 30 June 2020).

4. ICC and World Travel \& Tourism Council. Issue COVID-19 Restart Guide for the Travel \& Tourism Sector. Available online: https:/ / wttc.org/News-Article/ICC-and-World-Travel-and-Tourism-Council-issue-COVID-19-restart-guide-for-theTravel-and-Tourism-sector (accessed on 30 August 2020).

5. Li, F. A comparative study on the effect of tourism crisis events with different nature based on background line-A case study of four tourism crisis events in China. Tour. Trib. 2009, 24, 73-78.

6. Scott, N.; Laws, E. Tourism crises and disasters: Enhancing understanding of system impacts. J. Travel Tour. Mark. 2006, 19, 149-158. [CrossRef]

7. Chien, P.M.; Ritchie, B.W. Understanding intergroup conflicts in tourism. Ann. Tour. Res. 2018, 72, 177-179. [CrossRef]

8. Wang, I.M.; Ackerman, J.M. The infectiousness of crowds: Crowding experiences are amplified by pathogen threats. Pers. Soc. Psychol. Bull. 2019, 45, 120-132. [CrossRef]

9. Johannisson, B.; Olaison, L. The moment of truth-Reconstructing entrepreneurship and social capital in the eye of the storm. Rev. Soc. Econ. 2007, 65, 55-78. [CrossRef]

10. Page, S.; Song, H.; Wu, D.C. Assessing the impacts of the global economic crisis and swine flu on inbound tourism demand in the United Kingdom. J. Travel Res. 2012, 51, 142-153. [CrossRef]

11. Seabra, C.; Reis, P.; Abrantes, J.L. The influence of terrorism in tourism arrivals: A longitudinal approach in a Mediterranean country. Ann. Tour. Res. 2020, 80, 102811. [CrossRef]

12. Page, S.J.; Yeoman, I.; Munro, C.; Connell, J.; Walker, L. A case study of best practice-Visit Scotland's prepared response to an influenza pandemic. Tour. Manag. 2006, 27,361-393. [CrossRef]

13. Zeng, B.; Carter, R.W.; De Lacy, T. Short-term perturbations and tourism effects: The case of SARS in China. Curr. Issues Tour. 2005, 8, 306-322. [CrossRef]

14. Rittichainuwat, B.N.; Chakraborty, G. Perceived travel risks regarding terrorism and disease: The case of Thailand. Tour. Manag. 2009, 30, 410-418. [CrossRef]

15. Cahyanto, I.; Wiblishauser, M.; Pennington-Gray, L.; Schroeder, A. The dynamics of travel avoidance: The case of Ebola in the U.S. Tour. Manag. Perspect. 2016, 20, 195-203. [CrossRef]

16. Novelli, M.; Burgess, L.G.; Jones, A.; Ritchie, B.W. “No Ebola ... still doomed”-The Ebola-induced tourism crisis. Ann. Tour. Res. 2018, 70, 76-87. [CrossRef]

17. Williamson, J.; Hassanli, N.; Grabowski, S. OzNomads: A case study examining the challenges of COVID-19 for a community of lifestyle travellers. Curr. Issues Tour. 2021, 2021, 1928009.

18. Yang, Y.; Zhang, H.; Chen, X. Coronavirus pandemic and tourism: Dynamic stochastic general equilibrium modeling of infectious disease outbreak. Ann. Tour. Res. 2020, 83, 102913. [CrossRef]

19. Liu, B.; Pennington-Gray, L.; Krieger, J. Tourism crisis management: Can the Extended Parallel Process Model be used to understand crisis responses in the cruise industry? Tour. Manag. 2016, 55, 310-321. [CrossRef]

20. Luo, Q.; Zhai, X. "I will never go to Hong Kong again!" How the secondary crisis communication of "Occupy Central" on Weibo shifted to a tourism boycott. Tour. Manag. 2017, 62, 159-172. [CrossRef]

21. Aliperti, G.; Sandholz, S.; Hagenlocher, M.; Rizzi, F.; Frey, M.; Garschagen, M. Tourism, crisis, disaster: An interdisciplinary approach. Ann. Tour. Res. 2019, 79, 102808. [CrossRef]

22. Uğur, N.G.; Akbıyık, A. Impacts of COVID-19 on global tourism industry: A cross-regional comparison. Tour. Manag. Perspect. 2020, 36, 100744. [CrossRef]

23. Zhang, G. Public crisis management and government responsibility-A case study of SARS epidemic management. Manag. World 2004, 12, 42-50.

24. Li, J.; Nguyen, T.H.H.; Coca-Stefaniak, J.A. Coronavirus impacts on post-pandemic planned travel behaviours. Ann. Tour. Res. 2020, 2020, 102964. [CrossRef]

25. Ellis, S.; Sheridan, L. A critical reflection on the role of stakeholders in sustainable tourism development in least-developed countries. Tour. Plan. Dev. 2014, 11, 467-471. [CrossRef]

26. Hystad, P.W.; Keller, P.C. Towards a destination tourism disaster management framework: Long-term lessons from a forest fire disaster. Tour. Manag. 2008, 29, 151-162. [CrossRef]

27. Jiang, Y.; Ritchie, B.W. Disaster collaboration in tourism: Motives, impediments and success factors. J. Hosp. Tour. Manag. 2017, 31, 70-82. [CrossRef]

28. Freeman, R.E. Strategic Management: A Stakeholder Approach; Cambridge University Press: Cambridge, UK, 2010; ISBN 978-052115-1-740.

29. Baggio, R.; Scott, N.; Cooper, C. Improving tourism destination governance: A complexity science approach. Tour. Rev. 2010, 65, 51-60. [CrossRef] 
30. Leiper, N. Tourism Management, 3rd ed.; Pearson Education: Sydney, Australia, 2004; ISBN 186-250-5-330.

31. Waligo, V.; Clarke, J.; Hawkins, R. Embedding stakeholders in sustainable tourism strategies. Ann. Tour. Res. 2015, 55, 90-93. [CrossRef]

32. Kock, F.; Nørfelt, A.; Josiassen, A.; Assaf, A.G.; Tsionas, M.G. Understanding the COVID-19 tourist psyche: The evolutionary tourism paradigm. Ann. Tour. Res. 2020, 85, 103053. [CrossRef]

33. Hjalager, A.M. Repairing innovation defectiveness in tourism. Tour. Manag. 2002, 23, 465-474. [CrossRef]

34. Sundbo, J.; Orfila-Sintes, F.; Sørensen, F. The innovative behaviour of tourism firms-Comparative studies of Denmark and Spain. Res. Policy 2007, 36, 88-106. [CrossRef]

35. Cashdan, E.; Steele, M. Pathogen prevalence, group bias, and collectivism in the standard cross-cultural sample. Hum. Nat. 2013, 24, 59-75. [CrossRef]

36. Faulkner, J.; Schaller, M.; Park, J.H.; Duncan, L.A. Evolved disease-avoidance mechanisms and contemporary xenophobic attitudes. Group Process. Intergroup Relat. 2004, 7, 333-353. [CrossRef]

37. LeMoyne, É.; Chen, S.L.; Coursaris, C.K.; Sénécal, S.; Léger, P.M. The unintended consequences of COVID-19 mitigation measures on mass transit and car use. Sustainability 2020, 12, 9892. [CrossRef]

38. Hatipoglu, B.; Alvarez, M.D.; Ertuna, B. Barriers to stakeholder involvement in the planning of sustainable tourism: The case of the Thrace region in Turkey. J. Clean. Prod. 2016, 111, 306-317. [CrossRef]

39. Serravalle, F.; Ferraris, A.; Vrontis, D.; Thrassou, A.; Christofi, M. Augmented reality in the tourism industry: A multi-stakeholder analysis of museums. Tour. Manag. Perspect. 2019, 32, 100549. [CrossRef]

40. Sheehan, L.R.; Ritchie, J.R.B. Destination stakeholders exploring identity and salience. Ann. Tour. Res. 2005, 32, 711-734. [CrossRef]

41. Cai, G.; Kock, N. An evolutionary game theoretic perspective on e-collaboration: The collaboration effort and media relativeness. Eur. J. Oper. Res. 2009, 194, 821-833. [CrossRef]

42. Smith, J.M.; Price, G.R. The logic of animal conflict. Nature 1973, 246, 15-18. [CrossRef]

43. Li, Q.; Li, M.C.; Lv, L.; Guo, C.; Lu, K. A new prediction model of infectious diseases with vaccination strategies based on evolutionary game theory. Chaos Solitons Fractals 2017, 104, 51-60. [CrossRef]

44. Wang, L.; Schuetz, C.G.; Cai, D. Choosing response strategies in social media crisis communication: An evolutionary game theory perspective. Inf. Manag. 2020, 29, 103371.

45. Li, Y.; Ding, Y. Research on social trust repair of public crisis governance under network public opinion-Based on an empirical analysis of evolutionary game of animal epidemic public crisis. J. Public Manag. 2017, 14, 91-101.

46. Friedman, D. Evolutionary games in economics. Econometrica 1991, 59, 637-666. [CrossRef]

47. Barari, S.; Agarwal, G.; Zhang, W.J.; Mahanty, B.; Tiwari, M.K. A decision framework for the analysis of green supply chain contracts: An evolutionary game approach. Expert Syst. Appl. 2012, 39, 2965-2976. [CrossRef]

48. He, P.; He, Y.; Xu, F. Evolutionary analysis of sustainable tourism. Ann. Tour. Res. 2018, 69, 76-89. [CrossRef]

49. Blanco, E.; Lozano, J.; Rey-Maquieira, J. A dynamic approach to voluntary environmental contributions in tourism. Ecol. Econ. 2009, 69, 104-114. [CrossRef]

50. Smith, J.M. The theory of games and the evolution of animal conflicts. J. Theor. Biol. 1974, 47, 209-221. [CrossRef]

51. Taylor, P.D.; Jonker, L.B. Evolutionarily stable strategies and game dynamics. Math. Biosci. 1978, 40, 145-156. [CrossRef]

52. Zhao, L.; Chen, Z.; Liu, J. Evolutionary game theory between local government and tourism enterprises in the context of a low-carbon economy. Tour. Trib. 2015, 30, 72-82.

53. Zhong, L.; Sun, S.; Law, R.; Li, X. Tourism crisis management: Evidence from COVID-19. Curr. Issues Tour. 2021, $2021,1901866$.

54. Mohanty, P.; Hassan, A.; Ekis, E. Augmented reality for relaunching tourism post-COVID-19: Socially distant, virtually connected. Worldw. Hosp. Tour. Themes 2020, 12, 753-760.

55. Miao, L.; Im, J.; Fu, X.; Kim, H.; Zhang, Y.E. Proximal and distal post-COVID travel behavior. Ann. Tour. Res. 2021, 88, 103159. [CrossRef]

56. Chen, H.; Huang, X.; Li, Z. A content analysis of Chinese news coverage on COVID-19 and tourism. Curr. Issues Tour. 2020, 2020, 1763269. [CrossRef]

57. Sigala, M. Tourism and COVID-19: Impacts and implications for advancing and resetting industry and research. J. Bus. Res. 2020, 117, 312-321. [CrossRef] [PubMed]

58. Sheresheva, M.; Efremova, M.; Valitova, L.; Polukhina, A.; Laptev, G. Russian tourism enterprises' marketing innovations to meet the COVID-19 challenges. Sustainability 2021, 13, 3756. [CrossRef]

59. Fong, L.H.N.; Law, R.; Ye, B.H. Outlook of tourism recovery amid an epidemic: Importance of outbreak control by the government. Ann. Tour. Res. 2020, 25, 102951. [CrossRef]

60. Cohen, E.; Neal, M. Coinciding crises and tourism in contemporary Thailand. Curr. Issues Tour. 2010, 13, 455-475. [CrossRef]

61. Jenkins, C.L.; Henry, B.M. Government involvement in tourism in developing countries. Ann. Tour. Res. 1982, 9, 499-521. [CrossRef]

62. Kubickova, M.; Martin, D. Exploring the relationship between government and destination competitiveness: The TALC model perspective. Tour. Manag. 2020, 78, 104040. [CrossRef]

63. Rastegar, R. Tourism and justice: Rethinking the role of governments. Ann. Tour. Res. 2020, 2020, 102884. [CrossRef] 
64. Bramwell, B. Governance, the state and sustainable tourism: A political economy approach. J. Sustain. Tour. 2011, 19, 459-477. [CrossRef]

65. Ritchie, B.W.; Jiang, Y. A review of research on tourism risk, crisis and disaster management: Launching the annals of tourism research curated collection on tourism risk, crisis and disaster management. Ann. Tour. Res. 2019, 79, 102812. [CrossRef]

66. Nicola, M.; Alsafi, Z.; Sohrabi, C.; Kerwan, A.; Al-jabir, A.; Iosifidis, C.; Agha, M.; Agha, R. The socio-economic implications of the coronavirus pandemic (COVID-19): A review. Int. J. Surg. 2020, 78, 185-193. [CrossRef] [PubMed]

67. Liang, Y.H.; Yang, X.J. The game-theory analysis on regional tourism cooperation and competition. Geogr. Geoinf. Sci. 2005, 21, 94-97. 